\title{
Nutritional Value and Apparent Digestibility for Dry Matter, Protein, Energy and Essential Amino Acid in Ten Selected Feedstuffs for Juvenile Penaeus monodon
}

\author{
Xu Chen ${ }^{1}$, Qiang-Qiang Liu' ${ }^{1}$ Jia-Jun Xie ${ }^{1}$, Yun-Qiang Zhang ${ }^{2,3}$ and Jin $\mathrm{Niu}^{2 *}$ \\ ${ }^{1}$ Key Laboratory of Aquatic Product Processing, Ministry of Agriculture, South China Sea Fisheries Research Institute, Chinese Academy of Fishery Science, Guangzhou, \\ China \\ ${ }^{2}$ Nutrition Laboratory, Institute of Aquatic Economic Animals, School of Life Science, Sun Yat-sen University, Guangzhou, P.R. China \\ ${ }^{3}$ Guangdong Yuehai Feed Group Co. Ltd. Zhanjiang, P.R. China
}

\begin{abstract}
Nutritional values and apparent digestibility coefficients for dry matter (ADMD), protein (APD), energy (AED) and amino acid (AAAD) of ten feedstuffs were determined for juvenile shrimp, which included Peruvian steam fish meal, Peruvian FAQ fish meal, local fish meal, soybean meal, peanut meal, shrimp head meal, cottonseed meal, rapeseed meal, wheat flour and brewer's yeast. A reference diet and test diets that consisted of a 70:30 mixture of the reference diet to test feedstuff were used with $0.01 \%$ Yttrium oxide as an external marker. The eleven diets were fed to triplicate groups of juvenile Penaeus monodon (mean initial weight $1.13 \mathrm{~g} \pm 0.02 \mathrm{~g}$ ) for $56 \mathrm{days}$. After the 56-day trial, the highest and lowest values of weight gain (WG) and specific growth rate (SGR) of shrimp were found in shrimp head meal and cottonseed meal diet treatments, respectively. Feed conversion ratio (FCR) was in the range of 1.25-1.65. Peruvian steam fish meal and shrimp head meal diet treatments had the lowest FCR and cottonseed meal and rapeseed meal diet treatments had the highest FCR. The ADMD of diets is in the range of $63.52 \%$ to $80.07 \%$. The values of ADMD in shrimp head meal and wheat flour diets $(77.58 \%$ and $80.07 \%)$ were significantly higher than that in other diets $(P<0.05)$. APD, AAAD and AED differed greatly among feedstuffs, from $82.2 \%$ to $110.5 \%, 88.26 \%$ to $103.37 \%$ and $64.5 \%$ to $97.6 \%$, respectively. ADMD for the shrimp head meal, Peruvian FAQ fish meal and wheat flour were excellent (over 90\%), while brewer's yeast had lowest value of ADMD (under $60.52 \%$ ). Peanut meal, cottonseed meal, rapeseed meal and brewer's yeast had the lowest average AAAD ( 90\%). The average AAAD of Peruvian steam fish meal, Peruvian FAQ fish meal, local fish meal, soybean meal and shrimp head meal were nearly similar (95\% to $99 \%)$. Wheat flour had the highest average AAAD (106\%). In terms of ADMD, the most digestible ingredients were, in descending order, shrimp head meal, Peruvian FAQ fish meal, Peruvian steam fish meal, local fish meal for the marine feedstuffs; soybean meal and wheat flour are more preferable for $P$. monodon feed compared to other plant feedstuffs such as peanut meal, cottonseed meal and rapeseed meal.
\end{abstract}

Keywords: Penaeus monodon; Feedstuffs; Growth; Apparent digestibility coefficient

\section{Introduction}

Fish meal has been the most important feedstuff used as a source of protein in aquaculture feeds because of its essential amino acid composition and palatability [1]. Demand for protein ingredients in aquaculture is expected to exceed supply in the next decade. The sustainability of this sector depends, therefore, largely on the development of more cost-effective compounded feeds that rely less on costly protein sources such as fish meal. From an economical point of view, it is beneficial to use low-cost protein sources. The current trend is to decrease fish meal in aqua feeds and this has generated research for finding suitable alternative protein sources [2-8]. Although considerable progress has been made, most raw materials are deficient in one or more of the ten essential amino acids, especially methionine, the first limiting essential amino acid in plant and rendered animal byproducts. Protein and amino acids are considered expensive nutrients in feeds, and an oversupply of crude protein is the main cause of nitrogen contamination of pond water and environmental pollution [9]. Reduction in the dietary protein content without depressing amino acid requirements of shrimp can reduce feed costs and nitrogen pollution. Information on amino acid requirements and utilization in shrimp is undoubtedly one of the main issues limiting the development of shrimp feeding industry.

Despite accumulating evidences that free amino acids are utilized efficiently by fish and shrimp [2,5,10,11], leaching of nutrients and in particular of amino acids and other nitrogen-compounds is long recognized to lead to eutrophication of the water, thus negative impacting the environment. Diets have been usually evaluated in terms of growth with little attention to the digestibility. Generally, shrimp diets are formulated in terms of crude protein and amino acids content without considering the bioavailability of these ingredients. A feed may contain the adequate amount of nutrients formulated for a species but will just be wasted and detrimental to the environment if not efficiently assimilated. An effective feed can be prepared when information on digestibility of nutrients in feedstuffs has been considered in its formulation [12]. Thus, assessing the digestibility is the first step in evaluating the potential of a feedstuff for use in the diet of reared species [13]. Digestibility trials evaluate the nutritional value of a feedstuff which provides important information in growth measurements [14].

*Corresponding author: Jin Niu, Institute of Aquatic Economic Animals, School of Life Science, Sun Yat-sen University, Guangzhou 510275, P.R. China, Tel: +8620 84110789; Fax:+862084115896; E-mail: gzniujin2003@163.com, edls@mail.sysu.edu.cn

Received August 03, 2016; Accepted October 17, 2016; Published October 19 2016

Citation: Chen X, Liu QQ, Xie JJ, Zhang YQ, Niu J (2016) Nutritional Value and Apparent Digestibility for Dry Matter, Protein, Energy and Essential Amino Acid in Ten Selected Feedstuffs for Juvenile Penaeus monodon. J Aquac Res Development 7: 450. doi: 10.4172/2155-9546.1000450

Copyright: $\odot 2016$ Chen X, et al. This is an open-access article distributed under the terms of the Creative Commons Attribution License, which permits unrestricted use, distribution, and reproduction in any medium, provided the original author and source are credited. 
In China, traditional tiger shrimp, Penaeus monodon diets are typically comprised of Peruvian fish meal, soybean meal, peanut meal, wheat flour, brewer's yeast, shrimp head meal and vitamin and mineral supplements. Recently, with increasing prices of traditional feed ingredients, such as Peruvian fish meal and soybean meal, more alternative feedstuffs, such as local fish meal, cottonseed meal, rapeseed meal, are being used to partially replace high cost, traditional ingredients in tiger shrimp diets. Moreover, previous studies mainly focused on nutrient digestibility for shrimp have only reported values for crude protein and dry matter [15-18]. Data on amino acid digestive utilization coefficients is one of the most important factors in preparing adequate shrimp feeds and there is an increasing interest in defining feedstuff quality using as criterion the coefficients of amino acid digestibility [19-21]. Hence, creating a database of digestibility of amino acids could provide more useful, accurate, and flexible information for low cost formulation processes. However, digestibility studies of amino acids of these alternative ingredients and traditional feed ingredients are deficient for tiger shrimp, P. monodon. The purpose of this study was to determine the growth and apparent digestibility coefficients (ADCs) of dry matter, crude protein, energy and essential amino acids in feedstuffs used in diets for tiger shrimp, P. monodon.

\section{Methods and Materials}

\section{Feedstuffs}

A digestibility trial was conducted to determine the apparent digestibility coefficients of dry matter (ADMD), protein (APD), energy (AED) and amino acids (AAAD) for ten feed ingredients. These included three commercial fish meals; Peruvian steam fish meal; Peruvian FAQ fish meal; local fish meal; soybean meal; peanut meal; shrimp head meal; cottonseed meal; rapeseed meal; wheat flour; brewer's yeast. Peruvian steam fish meal, Peruvian FAQ fish meal, local fish meal and shrimp head meal were supplied by FOSHAN SHUNDE LIBAO Feed Co., LTD, P.R. China. Soybean meal, peanut meal, cottonseed meal, rapeseed meal, wheat flour and brewer's yeast were supplied by FOSHAN SHUNDE Feed Industrial Co., LTD, P.R. China. All the tested ingredients were cooked with a temperature at $92^{\circ} \mathrm{C}$, steam pressure of 140 PSI and with a 120 -second retention time before we got it.

\section{Formulation and diet preparation}

A reference diet (Table 1) was formulated to contain $\sim 41 \%$ crude protein and $\sim 7 \%$ lipids. A reference diet and test diets that consisted of a 70:30 mixture of the reference diet to test feedstuff were used with $0.01 \%$ Yttrium oxide as an external indicator. Table 2 lists the nutritional composition (dry matter, crude protein, crude lipid, gross energy, ash and gross phosphorus) of the test feedstuffs. Table 3 lists the proximate composition and amino acid content of the diets. Prior to preparing the diets, feed ingredients were pulverized and sieved (250 $\mu \mathrm{m})$. The dry ingredients of each diet were mixed thoroughly in a food mixer before soya lecithin, soybean oil and fish oil was added. After the oil was dispersed, water was added (approximately $40 \%$ of the total "as is" ingredient weight) and mixed. The resulting mixture was pelleted with a meat grinder and a $1.2 \mathrm{~mm}$ diameter die (Institute of Chemical Engineering, South China University of Technology, Guangzhou, P.R. China). The diets were dried in an oven at $60^{\circ} \mathrm{C}$ for $10 \mathrm{~h}$ and then the resulting pellets were dried at $25^{\circ} \mathrm{C}$ with the aid of air conditioner and an electrical fan until moisture was reduced to less than $10 \%$. The dry pellets were placed in plastic bags and stored $-20^{\circ} \mathrm{C}$ until used.

\section{Shrimp and experimental set up}

Juvenile $P$. monodon were obtained from a semi-intensive culture pond near Hongsha Bay, Sanya, Hainan province, China. Shrimp were acclimated to the experimental conditions and fed a commercial feed ( $41 \%$ crude protein) without yttrium oxide for 2 weeks before the experiment started. A total of 1320 shrimp with an initial body weight of $1.14 \mathrm{~g} \pm 0.03 \mathrm{~g}$ were distributed randomly into 33 fiberglass tanks (500L, $0.5 \mathrm{~m}^{2}$ bottom, 3 tanks per diet, 40 shrimp per tank). Water exchange in each tank was adjusted to approximately $1.0 \mathrm{~L} / \mathrm{min}$ with a flowing sand filtered water system (the thickness of the sand in the sand filter is $100 \mathrm{~cm}$ ). Each tank was covered by a plastic mesh lid to prevent shrimp from jumping out. The shrimp were cultured outdoors with a steel awning and subjected to a natural photoperiod. During the experimental period, the water temperature, salinity, dissolved oxygen and total ammonia nitrogen ranged from $26.8^{\circ} \mathrm{C}$ to $27.9^{\circ} \mathrm{C}, 29.0 \mathrm{~g} \mathrm{~L}^{-1}$ to $31.0 \mathrm{~g} \mathrm{~L}^{-1}, 6.5 \mathrm{~g} \mathrm{~L}^{-1}$ to $7.5 \mathrm{mg} \mathrm{L}^{-1}$ and $0.2 \mathrm{~g} \mathrm{~L}^{-1}$ to $0.3 \mathrm{mg} \mathrm{L}^{-1}$, respectively.

All shrimp in each tank were initially fed $6 \%$ of total body weight daily. The feeding frequency was three times per day at 7:00, 13:00, and 21:00 $\mathrm{h}$ and lasted for 56 days. During the feeding trial, the amount of diet given was progressively changed and adjusted according to the appetite of the shrimp by checking the bottom of the tanks for excess feed remaining $2 \mathrm{~h}$ after feeding. This way overfeeding was minimized and shrimp were fed close to satiation. Every morning and afternoon before each feeding time, all residual/uneaten feed, faeces, moults and dead shrimp were siphoned from tanks. Uneaten feed particles were dried and weighed and used for correction of feed intake. After 56 days of the breeding trial, feces started to be collected two times daily (8:00 and 14:00), approximately one hour after each feeding by gently

\begin{tabular}{|c|c|}
\hline \multicolumn{2}{|c|}{ Ingredients } \\
\hline Fish meal & 35 \\
\hline Soybean meal & 14 \\
\hline Peanut meal & 13.39 \\
\hline Wheat flour & 20 \\
\hline Brewer's yeast & 5 \\
\hline Shrimp head meal & 5 \\
\hline Soya lecithin & 1 \\
\hline Fish oil & 1 \\
\hline Soybean oil & 1 \\
\hline Choline chloride (50\%) & 0.5 \\
\hline $\mathrm{Ca}\left(\mathrm{H}_{2} \mathrm{PO}_{4}\right)_{2}-\mathrm{H}_{2} \mathrm{O}$ & 1 \\
\hline Vitamin premix* & 1 \\
\hline Mineral premix $†$ & 1 \\
\hline Sodium alginate & 1 \\
\hline Ascorbic phosphate ester & 0.1 \\
\hline $\mathrm{Yi}_{2} \mathrm{O}_{3}$ & 0.01 \\
\hline \multicolumn{2}{|c|}{ Nutrient levels $\ddagger$} \\
\hline Moisture & 6.08 \\
\hline Crude protein & 41.01 \\
\hline Crude lipid & 7.27 \\
\hline Ash & 12.77 \\
\hline \multicolumn{2}{|c|}{ 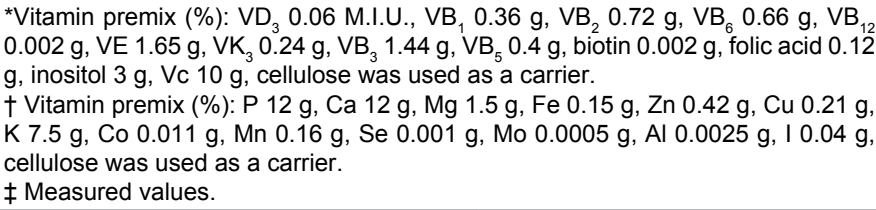 } \\
\hline
\end{tabular}

Table 1: Ingredient composition and nutrients levels (\% dry matter) of the reference diet used for the digestibility trial. 
Page 3 of 8

\begin{tabular}{|c|c|c|c|c|c|c|}
\hline Test feedstuffs & Day matter (\%) & Crude protein (\%) & Crude lipid (\%) & $\begin{array}{c}\text { Gross energy } \\
\left(\mathbf{k J ~ g}^{-1}\right)\end{array}$ & Ash (\%) & $\begin{array}{c}\text { Gross phosphorus } \\
(\%)\end{array}$ \\
\hline Peruvian steam fish meal & 92.08 & 70.91 & 10.29 & 21.80 & 13.50 & 2.24 \\
\hline Peruvian FAQ fish meal & 93.89 & 69.44 & 8.89 & 20.50 & 14.29 & 2.88 \\
\hline Local Fish meal & 91.58 & 69.77 & 10.00 & 19.70 & 17.79 & 2.69 \\
\hline Soybean meal & 90.93 & 50.01 & 1.80 & 19.30 & 4.26 & 0.75 \\
\hline Peanut meal & 90.04 & 55.37 & 5.02 & 19.00 & 5.25 & 0.89 \\
\hline Shrimp head meal & 90.15 & 42.08 & 1.01 & 12.80 & 22.66 & 1.28 \\
\hline Cottonseed meal & 93.71 & 44.13 & 1.20 & 19.00 & 5.01 & 1.26 \\
\hline Rapeseed meal & 92.59 & 41.94 & 1.71 & 19.50 & 6.93 & 1.17 \\
\hline Wheat flour & 90.88 & 18.28 & 0.70 & 17.80 & 1.22 & 0.30 \\
\hline Brewer's yeast & 91.70 & 44.40 & 0.68 & 17.68 & 6.47 & 1.20 \\
\hline
\end{tabular}

Table 2: Nutritional composition of test ingredients.

\begin{tabular}{|c|c|c|c|c|c|c|c|c|c|c|c|}
\hline \multirow[b]{2}{*}{ Nutrients } & \multicolumn{11}{|c|}{ Test diets (a $70: 30$ mixture of the reference diet to test feedstuffs) } \\
\hline & $\begin{array}{l}\text { Reference } \\
\text { diet }\end{array}$ & $\begin{array}{l}\text { Peruvian } \\
\text { steam fish } \\
\text { meal }\end{array}$ & $\begin{array}{c}\text { Peruvian FAQ } \\
\text { fish meal }\end{array}$ & $\begin{array}{c}\text { Local fish } \\
\text { meal }\end{array}$ & $\begin{array}{c}\text { Soybean } \\
\text { meal }\end{array}$ & $\begin{array}{l}\text { Peanut } \\
\text { meal }\end{array}$ & $\begin{array}{c}\text { Shrimp } \\
\text { head meal }\end{array}$ & $\begin{array}{l}\text { Cottonseed } \\
\text { meal }\end{array}$ & $\begin{array}{l}\text { Rapeseed } \\
\text { meal }\end{array}$ & $\begin{array}{l}\text { Wheat } \\
\text { flour }\end{array}$ & $\begin{array}{c}\text { Brewers } \\
\text { yeast }\end{array}$ \\
\hline Dry matter & 93.92 & 94.04 & 94.04 & 94.09 & 93.85 & 94.06 & 93.9 & 93.72 & 93.36 & 93.57 & 93.81 \\
\hline protein & 41.01 & 48.63 & 48.32 & 48.28 & 43.82 & 45.54 & 41.26 & 41.54 & 41.09 & 33.23 & 41.99 \\
\hline Lipid & 7.27 & 7.97 & 7.29 & 6.64 & 5.24 & 6.53 & 4.34 & 5.52 & 5.85 & 5.13 & 5.82 \\
\hline Ash & 12.77 & 13.86 & 13.57 & 18.72 & 10.09 & 10.51 & 20.13 & 10.41 & 10.73 & 9.26 & 10.62 \\
\hline $\mathrm{GE}\left(\mathrm{KJg}^{-1}\right)^{*}$ & 16.43 & 16.35 & 18.15 & 17.11 & 18.8 & 17.99 & 16.46 & 18.31 & 18.02 & 15.04 & 15.5 \\
\hline \multicolumn{12}{|c|}{ Amino acids } \\
\hline Lysine & 2.25 & 2.93 & 3.07 & 2.89 & 2.64 & 2.64 & 2.52 & 2.4 & 2.28 & 2.27 & 2.68 \\
\hline Phenylalanine & 1.53 & 1.63 & 1.71 & 1.62 & 1.77 & 1.79 & 1.43 & 1.73 & 1.57 & 1.54 & 1.67 \\
\hline Methionine & 0.85 & 0.88 & 0.88 & 0.87 & 0.82 & 0.84 & 0.84 & 0.79 & 0.78 & 0.78 & 0.88 \\
\hline Cysteine $†$ & 0.21 & 0.26 & 0.26 & 0.26 & 0.25 & 0.25 & 0.24 & 0.23 & 0.22 & 0.22 & 0.24 \\
\hline Threonine & 1.38 & 1.59 & 1.64 & 1.53 & 1.5 & 1.46 & 1.39 & 1.33 & 1.39 & 1.28 & 1.67 \\
\hline Isoleucine & 1.83 & 2.02 & 2.1 & 1.98 & 2.04 & 1.88 & 1.76 & 1.78 & 1.57 & 1.56 & 2.02 \\
\hline Valine & 2.01 & 2.2 & 2.31 & 2.17 & 2.19 & 2.17 & 1.91 & 2.07 & 1.98 & 1.94 & 2.28 \\
\hline Leucine & 2.76 & 3.11 & 3.24 & 3.02 & 3.33 & 2.99 & 2.59 & 2.72 & 2.6 & 2.54 & 3.01 \\
\hline Histidine & 0.97 & 1.12 & 1.18 & 1.11 & 1.02 & 1 & 0.84 & 1.01 & 0.98 & 0.94 & 1 \\
\hline Arginine & 2.43 & 2.73 & 2.77 & 2.73 & 2.71 & 3.3 & 2.38 & 3.08 & 2.58 & 2.56 & 2.36 \\
\hline DMWS $\ddagger$ & $9.34 \pm 0.06$ & $9.37 \pm 0.12$ & $9.29 \pm 0.06$ & $9.40 \pm 0.09$ & $\begin{array}{l}9.36 \pm \\
0.13\end{array}$ & $9.46 \pm 0.03$ & $9.52 \pm 0.05$ & $9.50 \pm 0.08$ & $9.39 \pm 0.05$ & $9.47 \pm 0.03$ & $9.36 \pm 0.17$ \\
\hline
\end{tabular}

Table 3: Proximate composition ( $\%$ dry matter), essential amino acid content ( $\%$ diet) and dry matter water stability in seawater at $27^{\circ} \mathrm{C}$ for 1 hour ( $\% \pm \mathrm{SD}$ ) of the reference and test diets.

siphoning fecal strands with a Pasteur pipette. If present, uneaten feed particles which were dyed red were easily sorted from the feces strands and discarded. Feces were gently rinsed with distilled water, transferred to $30 \mathrm{ml}$ conic tubes, and frozen at $-20^{\circ} \mathrm{C}$. Daily samples of frozen fecal material corresponding to each tank were pooled, freeze-dried, ground, thoroughly mixed, and kept frozen at $-80^{\circ} \mathrm{C}$ until analyzed. Sample collections were accumulated until $1.5 \mathrm{~g}$ dry weight of fecal material ( $\sim 15 \mathrm{~g}$ wet feces) from each tank had been collected.

\section{Sampling and chemical analysis}

Samples of the test ingredients and test diets were finely ground and sieved before chemical analysis. Moisture, crude protein, crude lipid and crude ash of the diets and feces were determined using standard methods [22]. Moisture was determined by oven drying at $105^{\circ} \mathrm{C}$ for $24 \mathrm{~h}$, and ash was determined using a muffle furnace at $550^{\circ} \mathrm{C}$ for $24 \mathrm{~h}$. Crude protein was analyzed by the Kjeldahl method after acid digestion (1030-Auto-analyzer, Tecator, Sweden). Crude lipid was determined by the ether-extraction method by Soxtec System HT (Soxtec System HT6, Tecator). Energy of the diets and fecal material were determined by an adiabatic micro-bomb calorimeter (HR-15A adiabatic calorimeter, Changshan, China). Yttrium (Y) was analyzed using inductivity couple plasma mass spectroscopy (ICP; model: IRIS Advantage (HR), Thermo Jarrel Ash Corporation, Boston, USA) [23]. The amino acid composition of all samples were analyzed following acid hydrolysis using an automatic amino acid analyzer (Hitachi 835-50, Japan) with a column (Hitachi custom ion exchange resin no. 2619) by Evonik Degussa (China) Co.Ltd. Novel product, Evonik Degussa Gmbh. In brief, performic acid oxidation was performed prior to hydrolysis to oxidize cystine and methionine to cysteic acid and methionine sulfone. Then sodium metabisulfite was added to decompose surplus performic acid. Subsequently, amino acids were liberated from protein by hydrolysis with $6 \mathrm{~N} \mathrm{HCl}$. Hydrolysed samples were diluted with sodium citrate buffer, $\mathrm{pH}$ was adjusted to 2.2 , and individual amino acid components were separated by ion exchange chromatography at $570 \mathrm{~nm}$. Tryptophan was not determined.

\section{Calculations and statistical analysis}

Biological parameters used to evaluate the quality of diets were calculated by equations as follows:

Weight gain (WG) $(\%)=100 \times\left(W_{f}-W_{i}\right) / W_{i}$ 
Specific growth rate $(\mathrm{SGR})\left(\%\right.$ day $\left.^{-1}\right)=100 \times\left(\ln W_{f}-\ln W_{i}\right) / t$

Survival $(\%)=100 \times N_{t} / N_{0}$

Feed conversion ratio $(\mathrm{FCR})=$ dry feed intake $/\left(W_{t}-W_{0}\right)$

$$
\mathrm{ADC}=\left[1-\left(\mathrm{Y}_{\mathrm{i}} / \mathrm{Y}_{\mathrm{f}}\right) \times\left(\mathrm{N}_{\mathrm{f}} / \mathrm{N}_{\mathrm{i}}\right)\right]
$$

Where $\mathrm{W}_{\mathrm{f}}$ and $\mathrm{W}_{\mathrm{i}}$ were mean final and initial shrimp body weights $t$ is the experimental duration in days; $\mathrm{N}_{t}$ is number of shrimp at the end of the trials and $\mathrm{N}_{0}$ at the start; $\mathrm{W}_{\mathrm{t}}(\mathrm{g})$ is total final body weight and $\mathrm{W}_{0}(\mathrm{~g})$ total initial body weight; $\mathrm{Y}_{\mathrm{i}}$ is trioxide yttrium content in feed; $\mathrm{Y}_{\mathrm{f}}$ is trioxide yttrium content in feces; $\mathrm{N}_{\mathrm{i}}$ is nutrient content in feed; $\mathrm{N}_{\mathrm{f}}$ is nutrient content in feces.

All data are presented as means \pm S.E.M. and subjected to one-way analysis of variance (ANOVA) to test the effects of experimental diets using the software of the SPSS for windows (ver 16.0, U.A.S). Duncan's new multiple range test was used to resolve the differences among treatment means [24]. Statistical significance was examined at $\mathrm{P}<0.05$ unless otherwise noted.

\section{Results}

\section{Growth performance}

Growth performance of $P$. monodon presented in Table 4 were significantly affected by dietary treatments $(P<0.05)$. Survival was in the range of $47.78 \%$ to $77.78 \%$, the highest and lowest values of survival of shrimp were found in shrimp head meal and cottonseed meal diet treatments, respectively $(\mathrm{P}<0.05)$; moreover, survival of shrimp in cottonseed meal diet treatment was significantly lower than that of shrimp in reference diet, Peruvian steam fish meal, shrimp head meal and brewer's yeast diet treatments $(\mathrm{P}<0.05)$ but without significant difference with other diet treatments $(\mathrm{P}>0.05)$. The highest and lowest values of WG of shrimp were found in shrimp head meal and cottonseed meal diet treatments, respectively $(\mathrm{P}<0.05)$; moreover, WG of shrimp in Peruvian steam fish meal was significantly higher than that of shrimp in reference diet treatment $(\mathrm{P}<0.05)$, and WG of shrimp in local fish meal and brewer's yeast diet treatments were significantly lower than that of shrimp in shrimp head meal diet treatment and higher than that of shrimp in other diet treatments except for local fish meal and brewer's yeast diet treatments; WG of shrimp in soybean meal diet treatment was significantly higher than that of shrimp in peanut meal, rapeseed meal and wheat flour diet treatments $(\mathrm{P}<0.05)$ but no significant difference was found in WG among peanut meal, rapeseed meal and wheat flour diet treatments $(P>0.05)$. SGR had the similar tendency with WG. FCR was in the range of 1.25-1.65. Cottonseed meal and rapeseed meal diet treatments had the highest FCR, followed by peanut meal, wheat flour, soybean meal, Peruvian FAQ fish meal, reference diet, brewer's yeast and local fish meal diet treatments, and finally the Peruvian steam fish meal and shrimp head meal diet treatments.

\section{Apparent digestibility coefficients (ADC, \%) for dry matter, crude protein, amino acid and energy in reference diet and test diets}

The ADMD, APD, AAAD and AED of reference diet and test diets consumed by P. monodon are shown in Table 5. The ADMD of diets is in the range of $63.52 \%$ to $80.07 \%$. The ADMD of shrimp head meal and wheat flour diets $(77.58 \%$ and $80.07 \%)$ were significantly higher than that of other diets $(\mathrm{P}<0.05)$. The ADMD of brewer's yeast diet $(63.52 \%)$

\begin{tabular}{|c|c|c|c|c|c|c|}
\hline Items & $\begin{array}{c}\text { Initial mean } \\
\text { weight/g }\end{array}$ & $\begin{array}{l}\text { Final mean } \\
\text { weight/g }\end{array}$ & Survival/\% & WG/\% & SGR/(\%/d) & FCR \\
\hline Reference diet & $1.12 \pm 0.02$ & $7.45 \pm 0.40^{e}$ & $70.56 \pm 5.71^{\mathrm{bc}}$ & $563.04 \pm 35.48^{e}$ & $3.15 \pm 0.09^{e}$ & $1.36 \pm 0.03^{b c}$ \\
\hline Peruvian steam fish meal & $1.15 \pm 0.01$ & $8.48 \pm 0.17^{h}$ & $70.00 \pm 6.67^{\mathrm{bc}}$ & $639.45 \pm 21.80^{f}$ & $3.33 \pm 0.05^{f}$ & $1.29 \pm 0.04^{\mathrm{ab}}$ \\
\hline Peruvian FAQ fish meal & $1.12 \pm 0.01$ & $6.04 \pm 0.13^{c}$ & $53.33 \pm 10.00^{\mathrm{ab}}$ & $441.38 \pm 14.91^{c}$ & $2.81 \pm 0.05^{c}$ & $1.40 \pm 0.04^{\mathrm{cd}}$ \\
\hline Local fish meal & $1.12 \pm 0.03$ & $7.75 \pm 0.24^{\text {ef }}$ & $57.78 \pm 11.71^{\mathrm{ab}}$ & $595.50 \pm 14.70^{\text {ef }}$ & $3.23 \pm 0.04^{\text {ef }}$ & $1.33 \pm 0.04^{\mathrm{bc}}$ \\
\hline Soybean meal & $1.11 \pm 0.01$ & $6.65 \pm 0.15^{d}$ & $63.33 \pm 8.82^{\mathrm{abc}}$ & $497.63 \pm 9.58^{d}$ & $2.98 \pm 0.03^{d}$ & $1.44 \pm 0.04^{\text {de }}$ \\
\hline Peanut meal & $1.12 \pm 0.01$ & $4.84 \pm 0.12^{\mathrm{ab}}$ & $62.22 \pm 13.47^{a b c}$ & $331.53 \pm 8.73^{\mathrm{ab}}$ & $2.44 \pm 0.03^{b}$ & $1.49 \pm 0.04^{e}$ \\
\hline Shrimp head meal & $1.15 \pm 0.03$ & $9.79 \pm 0.74$ & $77.78 \pm 5.09^{c}$ & $755.93 \pm 79.94^{g}$ & $3.57 \pm 0.15^{\mathrm{g}}$ & $1.25 \pm 0.03^{a}$ \\
\hline Cottonseed meal & $1.13 \pm 0.03$ & $4.36 \pm 0.19^{a}$ & $47.78 \pm 11.71^{\mathrm{a}}$ & $287.32 \pm 8.54^{\mathrm{a}}$ & $2.26 \pm 0.04^{a}$ & $1.65 \pm 0.04^{f}$ \\
\hline Rapeseed meal & $1.13 \pm 0.03$ & $5.02 \pm 0.08^{\mathrm{b}}$ & $53.33 \pm 3.33^{\mathrm{ab}}$ & $330.67 \pm 12.66^{\mathrm{ab}}$ & $2.43 \pm 0.05^{b}$ & $1.61 \pm 0.04^{f}$ \\
\hline Wheat flour & $1.13 \pm 0.02$ & $5.18 \pm 0.09^{b}$ & $61.11 \pm 12.62^{\mathrm{abc}}$ & $349.82 \pm 1.41^{b}$ & $2.51 \pm 0.01^{b}$ & $1.45 \pm 0.05^{\mathrm{de}}$ \\
\hline Brewer's yeast & $1.13 \pm 0.02$ & $8.19 \pm 0.19^{f g}$ & $72.22 \pm 10.72^{\mathrm{bc}}$ & $594.20 \pm 17.46^{\mathrm{ef}}$ & $3.23 \pm 0.04^{\mathrm{ef}}$ & $1.34 \pm 0.06^{b c}$ \\
\hline
\end{tabular}

In the same row, values with different small letter superscripts mean significant difference $(P<0.05)$.

Table 4: Growth performance of $P$. monodon fed with reference and test diets.

\begin{tabular}{|c|c|c|c|c|}
\hline Items & Dry matter & Protein & Amino acid & Energy \\
\hline Reference diet & $64.80 \pm 2.49^{\mathrm{ab}}$ & $83.84 \pm 1.71^{\mathrm{ab}}$ & $93.44 \pm 0.46^{\mathrm{cd}}$ & $83.11 \pm 0.93^{\mathrm{cd}}$ \\
\hline Peruvian steam fish meal & $69.12 \pm 1.89^{\mathrm{cd}}$ & $86.26 \pm 0.81^{c}$ & $94.42 \pm 0.34^{\mathrm{ef}}$ & $82.82 \pm 0.85^{\mathrm{bcd}}$ \\
\hline Peruvian FAQ fish meal & $72.92 \pm 1.68^{e}$ & $87.97 \pm 0.70^{d}$ & $94.22 \pm 0.36^{\mathrm{ef}}$ & $88.13 \pm 0.71^{f}$ \\
\hline Local Fish meal & $67.74 \pm 2.10^{\mathrm{bc}}$ & $86.11 \pm 0.90^{c}$ & $93.84 \pm 0.40^{\mathrm{de}}$ & $84.45 \pm 0.63^{\text {de }}$ \\
\hline Soybean meal & $71.40 \pm 2.68^{\mathrm{de}}$ & $88.47 \pm 0.63^{d}$ & $95.11 \pm 0.46^{g h}$ & $83.38 \pm 1.64^{\mathrm{cd}}$ \\
\hline Peanut meal & $65.85 \pm 2.39^{\mathrm{ab}}$ & $84.83 \pm 1.15^{\mathrm{bc}}$ & $92.84 \pm 0.50^{\mathrm{bc}}$ & $82.55 \pm 1.01^{b c}$ \\
\hline Shrimp head meal & $77.58 \pm 0.96^{f}$ & $88.70 \pm 0.41^{\mathrm{d}}$ & $95.24 \pm 0.21^{h}$ & $85.26 \pm 0.36^{e}$ \\
\hline Cottonseed meal & $71.56 \pm 0.91^{\mathrm{de}}$ & $85.49 \pm 0.31^{c}$ & $92.58 \pm 0.24^{b}$ & $81.23 \pm 1.24^{b}$ \\
\hline Rapeseed meal & $67.89 \pm 1.14^{\mathrm{bc}}$ & $85.55 \pm 0.38^{c}$ & $92.88 \pm 0.25^{\mathrm{bc}}$ & $81.71 \pm 0.66^{b c}$ \\
\hline Wheat flour & $80.07 \pm 0.40^{f}$ & $87.71 \pm 0.55^{d}$ & $94.56 \pm 0.11^{\mathrm{fg}}$ & $86.93 \pm 0.25^{f}$ \\
\hline Brewer's yeast & $63.52 \pm 0.62^{\mathrm{a}}$ & $83.33 \pm 0.21^{a}$ & $91.76 \pm 0.14^{a}$ & $76.89 \pm 0.71^{a}$ \\
\hline
\end{tabular}

*Including lysine, phenylalanine, methionine, cysteine, threonine, isoleucine, valine, leucine, histidine, arginine.

Table 5: Apparent digestibility coefficients (ADC, \%) for dry matter, crude protein, amino acid* and gross energy in the reference and test diets consumed by $P$. monodon. 
was significantly lower than that of wheat flour (80.07\%), shrimp head meal (77.58\%), Peruvian FAQ fish meal (72.92\%), cottonseed meal (71.56\%), soybean meal (71.40\%), Peruvian steam fish meal (69.12\%), rapeseed meal $(67.89 \%)$ and local fish meal $(67.74 \%)$ diets $(\mathrm{P}<0.05)$ but without significantly difference with peanut meal $(65.85 \%)$ and reference diets $(64.80 \%)$ ( $>0.05)$. The APD of diets varied from $83.33 \%$ to $88.70 \%$. The highest values of APD were shrimp head meal (88.70\%), soybean meal (88.47\%), Peruvian FAQ fish meal $(87.97 \%)$ and wheat flour $(87.71 \%$ ) diets, followed by Peruvian steam fish meal (86.26\%), local fish meal (86.11\%), rapeseed meal (85.55\%), cottonseed meal $(85.49 \%)$ and peanut meal (84.83\%) diets, and finally the brewer's yeast $(83.33 \%)$ and reference $(83.84 \%)$ diets. The AAAD of diets varied from $91.76 \%$ to $95.24 \%$. The highest values of AAAD were shrimp head meal (95.24\%) and soybean meal (95.11\%) diets, and the lowest value of AAAD was brewer's yeast $(91.76 \%)$ diet. The AED of diets varied from $76.89 \%$ to $88.13 \%$. The highest values of AED were Peruvian FAQ fish meal $(88.13 \%)$ and wheat flour $(86.93 \%)$ diets, and the lowest value of AED was brewer's yeast (76.89\%) diet.

\section{Apparent digestibility coefficients (ADC, \%) for dry matter, crude protein, amino acid and energy in test feedstuffs}

The ADMD, APD, AAAD and AED in feedstuffs consumed by $P$. monodon are shown in Table 6. The ADMD of test feedstuffs varied from $60.52 \%$ to $115.71 \%$. The highest values of ADMD were wheat flour (115.71\%) and shrimp head meal (107.40\%), and the lowest value of ADMD was brewer's yeast (60.52\%). The ADMD of Peruvian steam fish meal (79.19\%) was significantly lower than that of wheat flour (115.71\%), shrimp head meal (107.40\%) and Peruvian FAQ fish meal (91.87\%) and higher than that of peanut meal (68.30\%) and brewer's yeast $(60.52 \%)(\mathrm{P}<0.05)$ but without difference with cottonseed meal (87.31\%), soybean meal $(86.80 \%)$, rapeseed meal $(75.09 \%)$ and local fish meal $(74.60 \%)(\mathrm{P}>0.05)$. The APD of test feedstuffs varied from $82.18 \%$ to $110.46 \%$. The highest values of APD were wheat flour (110.46\%) and shrimp head meal (107.36\%), and the lowest value of APD was brewer's yeast (82.18\%). The APD of Peruvian steam fish meal (90.01\%) was significantly lower than that of wheat flour (110.46\%), shrimp head meal (107.36\%), soybean meal (98.85\%) and Peruvian FAQ fish meal (94.49\%) and higher than that of brewer's yeast $(82.18 \%)(\mathrm{P}<0.05)$ but without difference with rapeseed meal $(90.76 \%)$, local fish meal $(89.69 \%)$, cottonseed meal $(89.36 \%)$ and peanut meal $(86.78 \%)(\mathrm{P}>0.05)$. The AAAD of the test feedstuffs had the similar tendency with the APD. The AED of test feedstuffs varied from $64.51 \%$ to $97.62 \%$. The highest values of AED were Peruvian FAQ fish meal (97.62\%), wheat flour (94.70\%) and shrimp head meal (91.57\%), and the lowest values of AED was brewer's yeast (64.51\%). The AED of Peruvian steam fish meal $(90.01 \%)$ was significantly lower than that of Peruvian FAQ fish meal (97.62\%), wheat flour (94.70\%), shrimp head meal (91.57\%) and local fish meal (87.03\%) and higher than that of brewer's yeast $(64.51 \%)(\mathrm{P}<0.05)$ but without significant difference with soybean meal $(83.90 \%)$, peanut meal $(81.50 \%)$, rapeseed meal (78.97\%) and cottonseed meal (77.46\%) $(\mathrm{P}>0.05)$.

\section{Apparent digestibility coefficients (ADC, \%) of amino acids in test feedstuffs consumed by $P$. monodon}

The AAAD in feedstuffs consumed by $P$. monodon are shown in Table 7. In general, amino acid availability reflected protein digestibility. The values of AAAD of the ten feedstuffs ranged from $89.35 \%$ for lysine in cottonseed meal to $102.38 \%$ in wheat flour meal. Peanut meal, cottonseed meal, rapeseed meal and brewer's yeast hand the lower average AAAD ( $90 \%)$. The average AAAD of Peruvian steam fish meal, Peruvian FAQ fish meal, local fish meal, soybean meal and shrimp head meal were similar (95\% to 99\%). Wheat flour had the highest average AAAD (106\%). There were significant differences among individual amino acids. For example, digestibility of methionine was low in rapeseed meal $(82.75 \%)$ and high in shrimp head meal (97.25\%) and wheat flour (104.25\%); there were major differences between shrimp head meal and brewer's yeast in cysteine digestibility (103.45\% and $85.27 \%$, respectively). Phenylalanine was the less digestible in brewer's yeast, whereas lysine was the lowest in cottonseed meal and rapeseed meal.

\section{Discussion}

\section{Growth performance}

Over the 56 days experimental period, it was observed that the diet containing shrimp head meal induced a positive feeding response. However, the diet containing cottonseed meal was not readily accepted by the shrimp. This can likely be attributed to the presence of gossypol which occurs naturally in cottonseed and was described as higher levels of dietary cottonseed meal resulted in reduced performance of shrimp [25]. The favorable response of the shrimp to Peruvian steam fish meal, local fish meal, shrimp head meal and brewer's yeast diets compare to the reference diet is probably due to the high quality of these meals in terms of both nutrient profile and possibly digestibility as well as a lack of apparent palatability problems. Digestibility data reflect the percentage of a feed feedstuff sample that is absorbed from an animal's intestinal tract [26]. Using highly digestibility feedstuffs is especially important under high-density culture conditions, where accumulations of undigested feed can foul the water, affect the growth and immunity of shrimp [27]. By comparison, the apparent digestibility of animal-based ingredient, such as fish meal and shrimp head meal. Moreover, the favorable response of brewer's yeasts is also believed to have immune stimulatory properties by virtue of their complex carbohydrate components and nucleic acid content [28]. In brewer's

\begin{tabular}{|c|c|c|c|c|}
\hline Items & Dry matter & Protein & Amino acid & Energy \\
\hline Peruvian steam fish meal & $79.19 \pm 6.29^{\mathrm{cd}}$ & $90.01 \pm 2.05^{b}$ & $95.83 \pm 0.83^{c}$ & $82.26 \pm 2.48^{b c}$ \\
\hline Peruvian FAQ fish meal & $91.87 \pm 5.62^{\mathrm{e}}$ & $94.49 \pm 1.80^{c}$ & $95.35 \pm 0.88^{c}$ & $97.62 \pm 2.06^{f}$ \\
\hline Local Fish meal & $74.60 \pm 7.01^{\mathrm{bc}}$ & $89.69 \pm 2.31^{b}$ & $94.41 \pm 0.99^{c}$ & $87.03 \pm 1.85^{d}$ \\
\hline Soybean meal & $86.80 \pm 8.95^{\text {de }}$ & $98.85 \pm 2.03^{d}$ & $98.47 \pm 1.38^{d}$ & $83.90 \pm 4.83^{\mathrm{cd}}$ \\
\hline Peanut meal & $68.30 \pm 7.95^{\mathrm{ab}}$ & $86.78 \pm 3.44^{b}$ & $91.63 \pm 1.50^{b}$ & $81.50 \pm 2.92^{\mathrm{bc}}$ \\
\hline Shrimp head meal & $107.40 \pm 3.18^{f}$ & $107.36 \pm 1.49^{e}$ & $101.13 \pm 0.64^{e}$ & $91.57 \pm 1.42^{\mathrm{e}}$ \\
\hline Cottonseed meal & $87.31 \pm 3.02^{\mathrm{de}}$ & $89.36 \pm 1.02^{b}$ & $90.89 \pm 0.70^{\mathrm{b}}$ & $77.46 \pm 3.72^{b}$ \\
\hline Rapeseed meal & $75.09 \pm 3.80^{\mathrm{bc}}$ & $90.76 \pm 1.51^{\mathrm{bc}}$ & $91.49 \pm 0.88^{b}$ & $78.97 \pm 1.96^{b}$ \\
\hline Wheat flour & $115.71 \pm 1.34^{f}$ & $110.46 \pm 3.76^{e}$ & $103.37 \pm 0.98^{e}$ & $94.70 \pm 0.76^{e f}$ \\
\hline Brewer's yeast & $60.52 \pm 2.06^{a}$ & $82.18 \pm 0.67^{a}$ & $88.26 \pm 0.43^{a}$ & $64.51 \pm 2.12^{\mathrm{a}}$ \\
\hline
\end{tabular}

Table 6: Apparent digestibility coefficients (ADC, \%) for dry matter, crude protein, amino acid and energy in feedstuffs consumed by $P$. monodon. 


\begin{tabular}{|c|c|c|c|c|c|c|c|c|c|c|}
\hline \multirow[b]{2}{*}{ Amino acids } & \multicolumn{10}{|c|}{ Test feedstuffs } \\
\hline & $\begin{array}{c}\text { Peruvian } \\
\text { steam fish } \\
\text { meal }\end{array}$ & $\begin{array}{c}\text { Peruvian } \\
\text { FAQ fish } \\
\text { meal }\end{array}$ & $\begin{array}{l}\text { Local Fish } \\
\text { meal }\end{array}$ & $\begin{array}{l}\text { Soybean } \\
\text { meal }\end{array}$ & Peanut meal & $\begin{array}{l}\text { Shrimp head } \\
\text { meal }\end{array}$ & $\begin{array}{c}\text { Cottonseed } \\
\text { meal }\end{array}$ & $\begin{array}{l}\text { Rapeseed } \\
\text { meal }\end{array}$ & Wheat flour & Brewers yeast \\
\hline Lysine & $98.76 \pm 0.34^{e}$ & $96.79 \pm 0.45^{\mathrm{cd}}$ & $97.04 \pm 0.47^{\mathrm{d}}$ & $98.39 \pm 0.81^{e}$ & $91.12 \pm 1.50^{\mathrm{b}}$ & $98.94 \pm 0.33^{e}$ & $89.35 \pm 0.65^{a}$ & $89.40 \pm 0.68^{a}$ & $102.38 \pm 1.07^{f}$ & $95.55 \pm 0.18^{c}$ \\
\hline Phenylalanine & $93.17 \pm 1.16^{c}$ & $93.16 \pm 1.22^{\mathrm{c}}$ & $93.66 \pm 1.31^{\mathrm{c}}$ & $97.89 \pm 1.61^{\mathrm{d}}$ & $90.99 \pm 1.69^{b}$ & $98.62 \pm 0.77^{d}$ & $90.56 \pm 0.72^{b}$ & $94.35 \pm 0.97^{c}$ & $113.20 \pm 0.95^{\mathrm{e}}$ & $88.05 \pm 0.48^{a}$ \\
\hline Methionine & $93.33 \pm 0.95^{c}$ & $92.48 \pm 1.02^{c}$ & $90.47 \pm 1.23^{c}$ & $98.19 \pm 3.35^{d}$ & $86.44 \pm 2.72^{b}$ & $97.25 \pm 0.65^{d}$ & $83.60 \pm 1.14^{\mathrm{ab}}$ & $82.75 \pm 1.66^{a}$ & $104.25 \pm 1.29^{e}$ & $84.88 \pm 0.53^{\mathrm{ab}}$ \\
\hline Cysteine & $98.25 \pm 1.65^{c}$ & $99.20 \pm 1.58^{c}$ & $96.62 \pm 1.92^{c}$ & $102.99 \pm 3.17^{d}$ & $91.05 \pm 3.02^{\mathrm{b}}$ & $103.45 \pm 0.90^{d}$ & $90.76 \pm 1.03^{b}$ & $88.67 \pm 1.44^{b}$ & $118.16 \pm 1.13^{e}$ & $85.27 \pm 0.62^{a}$ \\
\hline Threonine & $95.88 \pm 0.90^{c}$ & $95.27 \pm 0.90^{\mathrm{c}}$ & $95.08 \pm 1.01^{c}$ & $99.73 \pm 1.54^{d}$ & $90.83 \pm 2.21^{b}$ & $100.39 \pm 0.66^{d}$ & $85.64 \pm 1.00^{\mathrm{a}}$ & $89.79 \pm 0.93^{b}$ & $101.04 \pm 1.63^{d}$ & $87.03 \pm 0.44^{a}$ \\
\hline Isoleucine & $96.99 \pm 0.91^{d}$ & $97.14 \pm 0.88^{d}$ & $97.16 \pm 0.97^{d}$ & $100.73 \pm 1.30^{e}$ & $91.15 \pm 2.02^{\mathrm{ab}}$ & $101.27 \pm 0.59^{e}$ & $89.45 \pm 0.96^{b}$ & $86.41 \pm 1.16^{\mathrm{a}}$ & $104.98 \pm 1.24^{f}$ & $92.62 \pm 0.37^{c}$ \\
\hline Valine & $94.20 \pm 1.12^{\mathrm{b}}$ & $94.10 \pm 1.13^{\mathrm{b}}$ & $94.14 \pm 1.25^{b}$ & $97.55 \pm 1.77^{c}$ & $87.10 \pm 2.29^{a}$ & $98.89 \pm 0.77^{c}$ & $88.07 \pm 0.94^{a}$ & $87.84 \pm 1.07^{\mathrm{a}}$ & $104.43 \pm 1.24^{\mathrm{d}}$ & $87.78 \pm 0.47^{a}$ \\
\hline Leucine & $96.68 \pm 0.70^{c}$ & $95.88 \pm 0.72^{\mathrm{c}}$ & $95.16 \pm 0.84^{c}$ & $99.04 \pm 1.05^{d}$ & $90.30 \pm 1.54^{\mathrm{a}}$ & $98.77 \pm 0.54^{d}$ & $89.57 \pm 0.74^{a}$ & $90.18 \pm 0.80^{\mathrm{a}}$ & $103.03 \pm 0.91^{\mathrm{e}}$ & $92.41 \pm 0.32^{b}$ \\
\hline Histidine & $96.16 \pm 0.70^{d}$ & $96.35 \pm 0.64^{d}$ & $96.19 \pm 0.77^{\mathrm{d}}$ & $97.31 \pm 1.14^{d}$ & $90.30 \pm 1.42^{b}$ & $99.88 \pm 0.62^{\mathrm{e}}$ & $89.49 \pm 0.60^{\mathrm{ab}}$ & $93.61 \pm 0.58^{c}$ & $101.00 \pm 0.87^{e}$ & $88.34 \pm 0.38^{a}$ \\
\hline Arginine & $97.24 \pm 0.50^{\text {cd }}$ & $97.84 \pm 0.48^{\mathrm{de}}$ & $96.79 \pm 0.56^{c}$ & $98.38 \pm 0.77^{e}$ & $97.03 \pm 0.50^{\mathrm{cd}}$ & $100.17 \pm 0.41^{f}$ & $97.19 \pm 0.21^{\mathrm{cd}}$ & $95.16 \pm 0.48^{b}$ & $109.01 \pm 0.67^{g}$ & $90.99 \pm 0.30^{a}$ \\
\hline
\end{tabular}

Table 7: Apparent digestibility coefficients (ADC, \%) of amino acids (excluding tryptophan and including cysteine) in test feedstuffs consumed by $P$. monodon.

yeast, nucleic acid nitrogen is present mostly in the form of RNA and represents about $20 \%$ to $25 \%$ of the nitrogen [29].

\section{Proximate composition and digestibility}

The protein quality of dietary ingredients is usually the leading factor affecting fish performance, bioavailability of proteins and amino acids in feedstuffs is an important factor to consider, in part because it is related to the quantity of nitrogen absorbed by shrimp. During high density cultivation, almost $78 \%$ of nitrogen from dietary protein is released to the environment [30]. Low digestibility of feeds leads to accumulation of nitrogen wastes in water and soil, which in turn can lead to shrimp disease and higher death rates [27], as well as pollution and eutrophication of water. Apparent dry matter digestibility provides a measure of the total quantity of an ingredient that is digested and absorbed. Because all components of a diet are not digested equally, ADMD can provide a better estimate of the quantity of indigestible material presented in a feed ingredient than digestibility coefficients for individual nutrients [15]. In the present study, the three fish meals were relatively similar in proximate composition, except Peruvian FAQ fish meal with lower lipid content $(8.89 \%)$, fish meal protein was well digested by juvenile $P$. monodon, which was higher than those reported for juvenile Litopenaeus vannamei [20,31]. Nutrient composition, quality and digestibility of amino acids in fish meals varies with the freshness and type of the raw ingredients and processing during manufacture [32]. According to other previous published research, fish meals used as an ingredient in feeds for shrimp should have at least $85 \%$ digestibility protein, contain $<150 \mathrm{~g} / \mathrm{kg}^{-1}$ ash, and dried at low temperatures to ensure good protein bioavailability and reduce nitrogen wastes that pollute the shrimp farms and outflow water [33]. These requirements were fulfilled by Peruvian steam fish meal and Peruvian FAQ fish meal. The differences in APD among the present fish meal could be attributed to several factors, such as different raw materials, location, or processing conditions used to produce the meal (steam or FAQ), as well as unknown factors. The differences in APD could also be a consequence of Maillard's reaction, which is known to reduce availability of amino acids caused by interaction between reducing sugars and amino acids [31]. However, this effect was not measured in this study. Further research is needed to confirm this hypothesis.

In the present study, the apparent digestibility for dry matter of some plant-based ingredients such as peanut meal $(68.30 \%)$ and rapeseed meal (75.09\%) were lower than that of soybean meal $(86.80 \%)$, cottonseed meal (87.31\%) and wheat flour $(115.71 \%)$. This is anticipated because peanut meal and rapeseed meal contain higher levels of ash than soybean meal. Increased use of plant-protein supplements in $P$. monodon diets will reduce feed cost and assist in reducing dependence on fish meal as the primary protein source in shrimp diet. In addition, soybean meal protein is considered to be highly digestible to many crustacean species [34]. Dry matter digestibility of feedstuffs consumed by $P$. monodon tended to decrease as the fibre and ash content of the feedstuffs increased. High-starch ingredients such as wheat flour tended to be better digested by P. monodon than those containing high quantities of fiber and ash. The low dry matter digestibility of some plant products appears to be related to the quantity and chemical composition of the carbohydrates they contain [35]. Rapeseed meal contains a high proportion of fiber besides other anti-nutritional factors such as tannins, sinapin and phytic acid [36]. Moreover, rapeseeds are also known to contain glycosylates, whose metabolites have a goitrogenic activity in all animals, including fish [37]. The low digestibility of rapeseed meal found in the present experiment was probably due to the high fibre and anti-nutritional factors [1].

Brewer's yeast is a source of nucleic acids and polysaccharides including glucans, it also contains proteins, vitamins, sixteen amino acids and fourteen or more minerals that are frequently used as feed ingredients in aquaculture [38]. In the present experiment, shrimp fed the brewer's yeast diet showed higher growth performance than in the reference diet. On the contrary, the ADMD, APD, AAAD and AED of brewer's yeast and brewer's yeast diet were lower than other feedstuffs and diets, indicating a lower digestible value of brewer's yeast than other feedstuffs. The digestible evaluation of brewer's yeast as feed ingredient in shrimp was scarce. The lower digestibility of shrimp fed brewer's yeast diet may be caused by intact yeast cells, as probably not all intracellular ingredients become available to the shrimp [39].

The proteins in tested diets were all highly digestible to $P$. monodon (Table 5). Crustaceans are proficient at digesting proteins as shown by the high protein to energy ratios in these species compared to those in fish [40]. The associative effects of nutrients in diets of crustaceans have been reported to affect feed digestibility especially the interactions of plant meals rich in carbohydrate and animal meals rich in protein [40]. It is clear in this study that for P. monodon, the relative amount of dietary protein had an effect on the ADMD (63.52\% to $80.07 \%)$ but not on APD (83.33\% to $88.70 \%)$. In P. monodon, increasing dietary carbohydrate could increase the crude fat in the feces [41]. However, no data has been available to understand the associative effects among feed ingredients in crustaceans. 


\section{Amino acids composition and digestibility}

The apparent amino acid digestibility coefficients varied from $89.35 \%$ for lysine in cottonseed meal to $102.38 \%$ for lysine in wheat flour. Physiologically, ADCs should range between $0 \%$ and $100 \%$. However, digestibility values higher than $100 \%$ have been reported in other studies $[15,19,42,43]$. Digestibility of some amino acids, such as lysine and methionine, may be overestimated because they are highly soluble in seawater [19]. A value of $110 \%$ for protein digestibility of wheat gluten was reported for P. setiferus [15], which was attributed to interactions among nutrients. Another factor that may affect apparent digestibility is the high temperatures that are sometimes used during manufacturing processes of feed ingredients. This may damage amino acids structure and affect digestibility (Maillard reaction), and they are eliminated in the urine without proper assimilation in the cells [31]. Hence, altered amino acids caused by high temperature processing can overestimate apparent digestibility.

No significant differences were found in AAAD among Peruvian steam fish meal, Peruvian FAQ fish meal and local fish meal; moreover, soybean meal and peanut meal had the comparable amino acids digestibility with the present three fish meals. However, shrimp head meal and wheat flour had the higher AAAD than the present three fish meals, and cottonseed meal, rapeseed meal and brewer's yeast had the lower AAAD than the present three fish meals. This suggested that soybean meal, peanut meal, shrimp head meal and wheat flour could be used as preferable ingredients in shrimp diets. Digestibility of cysteine was high in wheat flour; this amino acid is more easily altered by the Maillard reaction between reducing sugar and amino acids that occurs during heat processing of feed ingredients [31].

The apparent bioavailability of amino acids for soybean meal in the present manuscript was higher than the published research [14]. Soybean meal as in our study was demonstrated to be a good source of highly available amino acids for P. monodon. In general, the profile of amino acids for shrimp head meal in our study was higher than that of levels in the previous published research [21]. Moreover, ADMD, APD, AAAD and AED were higher in shrimp head meal than in fish meal. The higher digestibility of shrimp head meal may result from lower ash content and may be a good source of protein and amino acids for juvenile $P$. monodon. The nutrients in peanut meal vary with season and method of preparation, which is probably sufficient to lead to changes in digestibility. The present amino acids digestibilities of cottonseed meal and rapeseed meal were comparable to other test feedstuffs though significant differences were found among them. Our results suggest that cottonseed meal and rapeseed meal could be the good source of protein and amino acids for P. monodon by removing the anti-nutritional factors in a proper way [1]. No previous reports appear to consider amino acids digestibilities of cottonseed meal and rapeseed meal by the shrimp.

\section{Conclusion}

Great variability in the coefficients of apparent digestibility of dry matter, protein and amino acids of ten feedstuffs was found in the present study. These variables should be considered in substitution of total protein by amino acids for more accurate and economical formulation of shrimp feeds. The most digestible ingredients were, in descending order, shrimp head meal, Peruvian FAQ fish meal, Peruvian steam fish meal, local fish meal for the marine feedstuffs; soybean meal and wheat flour are more preferable for $P$. monodon feed compared to other plant feedstuffs such as peanut meal, cottonseed meal and rapeseed meal; brewer's yeast induced a positive feeding and growth response in P. monodon though its digestibility is poor, it might also be of interest to study the effect of processing technology on nutrients digestibility of brewer's yeast.

\section{Acknowledgements}

This research was supported by Special Project of National Oceanic and Economic Innovation and Development of Guangdong Province (SZHY2012-B01-005) (GD2013-B02-002), and Science and Technology of Guangdong Province (2013B090600045). The authors thank the participants who gave their time to the trial. Jin Niu and Hei-Zhao Lin designed the study. Yun-Qiang Zhang and Xu Chen carried out the rearing work. Jun Wang and Yun Wang helped analyzed the samples. Xu Chen analyzed the results and wrote the paper with contributions from the other authors.

\section{Conflict of Interest}

There are no conflicts of interest.

\section{References}

1. Burel C, Boujard T, Tulli F, Kaushik SJ (2000) Digestibility of extruded peas, extruded lupin, and rapeseed meal in rainbow trout (Oncorhynchus mykiss) and turbot (Psetta maxima). Aquaculture 188: 285-298.

2. Gómez-Requeni $P$, Mingarro M, Calduch-Giner JA, Médale F, Martin SAM, et al. (2004) Protein growth performance, amino acid utilisation and somatotropic axis responsiveness to fish meal replacement by plant protein sources in gilthead sea bream (Sparus aurata). Aquaculture 232: 493-510.

3. Sitjà-Bobadilla $A$, Peña-Llopis $S$, Gómez-Requeni $P$, Médale $F$, Kaushik $S$, et al. (2005) Effect of fish meal replacement by plant protein sources on nonspecific defence mechanisms and oxidative stress in gilthead sea bream (Sparus aurata). Aquaculture 249: 387-400.

4. Martínez-Llorens S, Moñino AV, Tomás A, Pla M, Jover M (2007) Soybean meal as partial dietary replacement for fish meal in gilthead sea bream (Sparus aurata) diets: effects on growth, nutritive efficiency and body composition. Aquacult Res 38: 82-90.

5. Kaushik SJ, Covès D, Dutto G, Blanc D (2004) Almost total replacement of fish meal by plant protein sources in the diet of a marine teleost, the European seabass, Dicentrarchus labrax. Aquaculture 230: 391-404.

6. Tibaldi E, Hakim Y, Uni Z, Tulli F, Francesco M, et al. (2006) Effects of the partial substitution of dietary fish meal by differently processed soybean meals on growth performance, nutrient digestibility and activity of intestinal brush border enzymes in the European sea bass (Dicentrarchus labrax). Aquaculture 261: $182-193$

7. Biswas AK, Kaku H, Ji SC, Seoka M, Takii K (2007) Use of soybean meal and phytas for partial replacement of fish meal in the diet of red sea bream, Pagrus major. Aquaculture 267: 284-291.

8. Lim SR, Choi SM, Wang XJ, Kim KW, Shin IS, et al. (2004) Effects of dehulled soybean meal as a fish meal replacer in for fingerling and growing Korean rockfish SeBastes schlegeli. Aquaculture 231: 457-468.

9. Primavera $\mathrm{JH}$ (2005) Mangroves, fishponds, and the quest for sustainability. Science 310: 57-59.

10. Millamena OM, Teruel MB, Kanazawa A, Teshima S (1999) Quantitative dietary requirements of postlarval tiger shrimp, Penaeus monodon, for histidine isoleucine, leucine, phenylalanine and tryptophan. Aquaculture 179: 169-179.

11. Niu J, Du Q, Lin HZ, Chen YQ, Huang Z, et al. (2013) Quantitative dietary methionine requirement of juvenile golden pompano Trachinotus ovatus at a constant dietary cystine level. Aquacult Nutr 19: 677-686

12. Catacutan MR, Eusebio PS, Teshima SI (2003) Apparent digestibility of selected feedstuffs by mud crab, Scylla serrata. Aquaculture 216: 253-261.

13. Allan GL, Parkinson S, Booth MA, Stone DAJ, Rowland SJ, et al. (2000) Replacement of fish meal in diets for Australian silver perch, Bidyanus bidyanus: I. Digestibility of alternative ingredients. Aquaculture 186: 293-310.

14. Akiyama DM, Coelho SR, Lawrence AL, Robinson EH (1989) Apparent digestibility of feedstuffs by the marine shrimp Penaeus vannamei, Boone. Nippon Suisan Gakk 55: 91-98.

15. Brunson JF, Romaire RP, Reigh RC (1997) Apparent digestibility of selected ingredients in diets for white shrimp Penaeus setiferus L. Aquacult Nutr 3: 9-16.

16. Sudaryono A, Tsvetnenko E, Evans LH (1999) Evaluation of potential of lupin 
Citation: Chen X, Liu QQ, Xie JJ, Zhang YQ, Niu J (2016) Nutritional Value and Apparent Digestibility for Dry Matter, Protein, Energy and Essential Amino Acid in Ten Selected Feedstuffs for Juvenile Penaeus monodon. J Aquac Res Development 7: 450. doi: 10.4172/2155-9546.1000450

Page 8 of 8

meal as an alternative to fishmeal in juvenile Penaeus monodon diets. Aquacult Nutr 5: 277-285

17. Sudaryono A, Tsvetnenko E, Hutabarat J, Supriharyono E (1999) Lupin ingredients in shrimp (Penaeus monodon) diets: influence of lupin species and types of meals. Aquaculture 171: 121-133.

18. Bautista-Teruel MN, Eusebio PS, Welsh TP (2003) Utilization of feed pea Pisumsativum, meal as a protein source in practical diets for juvenile tiger shrimp, Penaeus monodon. Aquaculture 225: 121-131.

19. Cruz-Suárez LE, Tapia-Salazar M, Villarreal-Cavazos D, Beltran-Rocha J, Nieto-López MG, et al. (2009) Apparent dry matter, energy, protein and amino acid digestibility of four soybean ingredients in white shrimp Litopenaeus vannamei juveniles. Aquaculture 292: 87-94.

20. Lemos D, Lawrence AL, Siccardi AJ (2009) Prediction of apparent protein digestibility of ingredients and diets by in vitro $\mathrm{pH}$ stat degree of protein hydrolysis with species-specific enzymes for juvenile Pacific white shrimp Litopenaeus vannamei. Aquaculture 295: 89-98.

21. Yang Q, Zhou X, Zhou Q, Tan B, Chi S, et al. (2009) Apparent digestibility of selected feed ingredients for white shrimp Litopenaeus vannamei, Boone. Aquacult Res 40: 1-9.

22. Association of Official Analytical Chemists (1995) Official Methods of Analysis of Official Analytical Chemists International (16thedn). Association of Official Analytical Chemists, Arlington, VA, USA

23. Refstie S, Helland SJ, Storebakken T (1997) Adaptation to soybean meal in diets for rainbow trout (Oncorhynchus mykiss). Aquaculture 153: 263-272.

24. Duncan DB (1955) Multiple-range and multiple F tests. Biometrics 11: 1-42.

25. Davis DA, Arnold CR (2000) Replacement of fish meal in practical diets for the Pacific white shrimp, Litopenaeus Vannamei. Aquaculture 185: 291-298.

26. Lin HZ, Guo ZX, Yang YY, Zheng WH, Li ZJ (2004) Effect of dietary probiotics on apparent digestibility coefficients of nutrients of white shrimp Litopenaeus vannamei Boone. Aquacult Res 35: 1441-1447.

27. Lin HZ, Li ZJ, Chen YQ, Zheng WH, Yang K (2006) Effect of dietary traditional Chinese medicines on apparent digestibility coefficients of nutrients for white shrimp Litopenaeus vannamei, Boone. Aquaculture 253: 495-501.

28. Anderson DP, Siwicki AK, Rumsey GL (1995) Injection or immersion delivery of selected immunostimulants to trout demonstrate enhancement of nonspecific defense mechanisms and protective immunity. Diseases in Asian Aquaculture: II. Fish Health Section. Asian Fisheries Society, Manila.

29. Rumsey GL, Kinsella JE, Shetty KJ, Hughes SG (1991) Effect of high dietary concentrations of brewer's dried yeast on growth performance and liver uricase in rainbow trout (Oncorhynchus mykiss). Anim Feed Sci Technol 33: 177-183.

30. Jackson C, Preston N, Thompson PJ, Burford M (2003) Nitrogen budget and effluent nitrogen components at an intensive shrimp farm. Aquaculture 218 : 397-411.

31. Terrazas-Fierro M, Civera-Cerecedo R, Ibarra-Martínez L, Goytortúa-Bores E Herrera-Andrade M, et al. (2010) Apparent digestibility of dry matter, protein, and essential amino acid in marine feedstuffs for juvenile whiteleg shrimp Litopenaeus vannamei. Aquaculture 308: 166-173.

32. Smith DM, Tabrett SJ, Barclay MC, Irvin SJ (2005) The efficacy of ingredients included in shrimp feeds to stimulate intake. Aquaculture Nutrition 11: 263-272.

33. Cruz-Suárez LE, Nieto-López M, Guajardo-Barbosa C, Tapia-Salazar M Scholz U, et al. (2007) Replacement of fish meal with poultry by-product meal in practical diets for Litopenaeus vannamei, and digestibility of the tested ingredients and diets. Aquaculture 272: 466-476.

34. Mu Y, Lam T, Guo J, Shim K (2000) Protein digestibility and amino acid availability of several protein sources for juvenile Chinese hairy crab Eriocheir sinensis H Milne-Edwards (Decapoda, Grapsidae). Aquacult Res 31: 757-765.

35. Lupatsch I, Kissil GW, Sklan D, Pfeffer E (1997) Apparent digestibility coefficients of feed ingredients and their predictability in compound diets for gilthead seabream Sparus aurata L. Aquacult Nutr 3: 81-89.

36. Yurkowski M, Bailey JK, Evans RE, Tabachek JAL, Burton Ayles G (1978) Acceptability of rapeseed proteins in diets of rainbow trout (Salmo gairdneri). $J$ Fish Res Board Can 35: 951-962.

37. Teskeredzic Z, Higgs DA, Dosanjh BS, McBride JR, Hardy RW, et al. (1995) Assessment of undephytinized and dephytinized rapeseed protein concentrate as sources of dietary protein concentrate as sources of dietary protein for juvenile rainbow trout (Oncorhynchus mykiss). Aquaculture 131: 261-277.

38. Oliva-Teles A, Gonçalves P (2001) Partial replacement of fishmeal by brewer's yeast (Saccaromyces cerevisae) in diets for sea bass (Dicentrarchus labrax) juveniles. Aquaculture 202: 269-278.

39. Rumsey GL, Hughes SG, Kinsella JL (1990) Use of dietary yeast Saccharomyces cerevisiae nitrogen by lake trout. J World Aquac Soc 21: 205-209.

40. Lee GP, Lawrence LA (1997) Digestibility. Advances in World Aquaculture. World Aquaculture Society. Louisiana State University, Baton Rouge, Louisiana.

41. Catacutan M (1991) Apparent digestibility of diets with various carbohydarte levels and the growth response of Penaeus monodon. Aquaculture 95: 89-96.

42. Rivas-Vega ME, Rouzaud-Sandez O, Salazar-García MG, Ezquerra-Braue JM, Goytortúa-Bores E, et al. (2009) Physicochemical properties of cowpea (Vigna unguiculata L. Walp.) meals and their apparent digestibility in white shrimp (Litopenaeus vannamei Boone). Hidrobiológica 19: 15-23.

43. Nieto-López M, Tapia-Salazar M, Ricque-Marie D, David VC, Lemme A et al. (2011) Digestibility of different wheat products in white shrimp Litopenaeus vannamei juveniles. Aquaculture 319: 369-376. 